\title{
As Duas Definições de Prazer na Ética Nicomaqueia de Aristóteles
}

\author{
Juliana Aggio
}

The purpose of the text is to show how Aristotle, in formulating the first definition of pleasure in direct opposition to Plato's definition, poses for himself a conceptual trap to be overcome with the formulation of the second definition of pleasure. The first definition of pleasure - unimpeded activity of the natural state and not a restorative process of a weak state - poses the following trap: if eudaimonia is also an unimpeded activity of the natural state, what would prevent the whole identification of this with pleasure? It occurs that Aristotle does not advocate a radical hedonistic position, despite having argued dialectically that pleasure would, in some way, be the supreme good. Given the problem, we will show how the second definition of pleasure - activity following another activity - is necessary to avoid a possible radical hedonism aroused by the first definition. In so doing, the logical link between the Treaties will be evident, what is contrary to the interpretation of most commentators.

\section{Preâmbulo}

Definir o prazer nunca foi tarefa fácil na filosofia. Aristóteles se coloca o desafio em sua obra Ética Nicomaqueia justamente por que, segundo o filósofo, nenhuma ética poderia se eximir de tratar de um assunto tão importante. A importância maior é que o prazer, agarrado à nossa natureza desde sempre e travestido de uma aparência de bem, conduz as nossas ações facilmente para o erro moral. Todavia, ainda que sob este estigma negativo, não haveria eudaimonia, bem-viver, sem o prazer. Justificativa dada sobre a necessidade de se saber o que é o prazer, Aristóteles se lança na difícil empreitada de defini-lo.

Os problemas da primeira definição de prazer

No início do primeiro Tratado, Aristóteles expõe as três opiniões conflitantes sobre o valor moral do prazer. A primeira é a de que o prazer deve ser evitado 
absolutamente, visto que é um mal per se ou per accidens. Esta posição radicalmente antihedonista é atribuída pelo Estagirita a Espeusipo (1153b5-7). A segunda afirma que o homem deve dominar, controlar, refrear os seus apetites (epithumiai) ${ }^{1}$, visto que, senão todos, com certeza a maioria dos prazeres é má. Esta opinião, também anti-hedonista, embora não extremada, se justifica pelo fato de haver prazeres que são vergonhosos e censuráveis, bem como outros tantos que são nocivos (1152b21-22). A justificativa parece referir-se à concepção que Platão expressa em seu diálogo Filebo ${ }^{2}$ ao dizer que a maioria dos prazeres nocivos é corporal e envolve dor. Por fim, a terceira opinião expressa uma posição menos radical, que também aparece no final do diálogo referido ${ }^{3}$ e com a qual parece concordar Aristóteles em seu segundo Tratado, a saber: o prazer não poderia ser o bem supremo, mesmo que todos os prazeres fossem bons. Esta última opinião, que pode ser entendida como hedonista moderada, se contrapõe à concepção hedonista extremada sustentada por Eudoxo (EN X 2,1172b9), que acredita que o prazer seja o bem por excelência.

Resumidamente, há três opiniões que serão examinadas e criticadas por Aristóteles para que o mesmo possa chegar à sua própria concepção de prazer neste primeiro Tratado, a saber: uma opinião radicalmente anti-hedonista, outra anti-hedonista simplesmente, e, uma terceira, por assim dizer, hedonista moderada, e mais próxima do que pensa o filósofo Estagirita. ${ }^{4}$ A opinião hedonista extrema de Eudoxo será examinada apenas no segundo Tratado.

${ }^{1}$ Gostaria de esclarecer, por questão de convenção, que optei traduzir o termo orexis por desejo; boulêsis por querer; epithumia por apetite, e thumos por impulso.

${ }^{2}$ Para Gauthier (L'Ethique à Nicomaque, tome II. Paris: Ed. Peeters, 2002), esta segunda opinião seria platônica, pois Platão, em Filebo (50e - 53c; 66c), diz que os bons prazeres são apenas os da alma - aqueles que não envolvem dor, que são puros, imaculados e suficientes, i.e., não carentes ou deficientes em sua natureza. São também moderados, poucos, belos e mais próximos da verdade. São os que nascem da apreensão das formas geométricas, de belas cores, de muitos odores e de sons suaves e límpidos, próprios de uma melodia pura e única, e, sobretudo, o prazer da aprendizagem. Em suma, os prazeres puros são aqueles que acompanham o conhecimento e algumas sensações. Já os prazeres ruins são aqueles que envolvem dor por serem extremos ou desmedidos, e esses são grandes e numerosos, pois constituem a maioria dos prazeres corporais, principalmente, os sexuais.

${ }^{3}$ Cf. Filebo 60d-61b, em que Platão propõe que a vida feliz seja mista entre prazer e inteligência. Aristóteles atribui textualmente a Platão esta terceira opinião em EN X 2: 1172b29.

${ }^{4}$ Tomás de Aquino (1993, § 1481), Festugière (Le Plaisir, Paris, 1946) e Joachim (The Nicomachean Ethics, Oxford, 1955) atribuíram esta terceira opinião a Aristóteles. Riel (Pleasure and the Good Life. Boston: Brill, 2000), por sua vez, critica tal atribuição, pois a justificativa do prazer não ser o bem supremo é a de que ele é um processo (genesis), o que certamente não pode ser um argumento aristotélico. Acresce ainda, que esta concepção é antes de Platão do que de Aristóteles. Em concordância com Riel, dizemos que ela se aproxima apenas no que diz respeito 
O principal objetivo deste primeiro Tratado é o de refutar a visão radicalmente anti-hedonista com vistas a demonstrar que a felicidade pressupõe o prazer e que, portanto, o bem supremo não poderia incluir um mal em sua constituição; por este motivo, o prazer deve ser considerado um bem. Isso significa que a concepção anti-hedonista está, por assim dizer, mais distante da verdade do que a concepção hedonista. Prova disto é o fato de Aristóteles fazer uso do mesmo argumento do qual parte Eudoxo ${ }^{5}$ para fundamentar o seu hedonismo, a saber: o prazer é naturalmente perseguido por todos os animais. Ora, conceber que a natureza do animal busca algo que seja um mal para si parece ser um contrassenso factual e teórico, pois sabemos que, para o filósofo, a essência (eidos) de cada coisa busca naturalmente o seu bem próprio. É evidente, aos olhos de quem examina com a atenção este primeiro Tratado, que o principal alvo de Aristóteles é a concepção anti-hedonista. Para atingir o seu alvo, ele expõe os argumentos que sustentam tal concepção no capítulo 11, e, no capítulo seguinte, passa a refutá-los.

A opinião de que o prazer não é um bem nem em si mesmo (per se), nem por acidente (per accidens), pretende se sustentar pelas seguintes razões: em primeiro lugar, (i) o prazer é um processo sensível (genesis aisthêtê) com vistas à natureza, e (ii) o processo é distinto do fim do processo, pois o processo existe em vista do fim que, por sua vez, existe em vista de si mesmo; (iii) então, o fim deve ser concebido como o bem ao qual visa o processo e esse, por sua vez, não é um bem. Conclusão: o prazer, sendo um processo, tampouco poderia ser um bem. ${ }^{6}$ Em segundo lugar, (i) como o temperante (sôphrôn) evita os prazeres $^{7}$ e (ii) é ele quem serve de modelo para a busca do bem, então,

à sua postulação, i.e., o prazer não é o bem, embora possa ser um bem; porém, a sua justificativa não pode ser aristotélica.

${ }^{5}$ Cf. EN X 2: 1172b9-10 e I 12: 1101b27-31.

${ }^{6}$ Este argumento certamente é de Platão, pois está presente em Filebo 53c-55c. Riel (2000, pg. 47) e Frede (2005, pg.189) também localizam o argumento no diálogo referido. Ver também $M M$ II 7: 1204b4-1205a7. O argumento, a meu ver, não parece ser fiel ao que procurou dizer Platão, pois, ainda que, segundo o mesmo, alguns sábios tenham dito que o prazer, em geral, é devir, a sua própria concepção não seria a de que todo prazer seja ruim por ser um vir a ser, mas apenas os impuros, aqueles que são misturados com a dor, que são um processo sensível de restauração do estado natural, pois nascem de um estado dolorido de falta ou carência; esses são, comumente, os prazeres do corpo. Aos olhos do Estagirita, porém, Platão estaria se referindo a todo prazer e não apenas ao corporal.

${ }^{7}$ É provável que este argumento se refira ao diálogo Fédon (68c) de Platão, no qual ele afirma que o temperante evita os apetites, enquanto o intemperante busca tais prazeres a ponto de se tornar escravo deles. Mais uma vez, Platão estaria criticando apenas o prazer corporal e não todo e qualquer prazer, como parece pressupor Aristóteles. Sobre este ponto ver também Frede (2005, pg. 190). 
o prazer não deve ser considerado um bem. Em terceiro lugar, o prudente (phronimos) busca o que não é penoso, e não o que é prazeroso, logo, (i) se o prudente busca o bem e (ii) este é antes o que não é penoso do que o que é prazeroso, conclui-se que buscar o bem é evitar o que é penoso e não perseguir o prazeroso. Em quarto lugar, o prazer é um impedimento do exercício do pensamento ${ }^{8}$, então ele deve ser considerado não acidentalmente, mas essencialmente um obstáculo para a realização da prudência. Assim, (i) se prazer é um impedidor da prudência e (ii) nada que seja bom a impediria, então o prazer não poderia ser um bem. Em quinto lugar, (i) como todo bem é produzido por uma arte (technê), e (ii) não há arte que produza o prazer, segue-se que o prazer não poderia ser um bem. ${ }^{9}$ Em sexto e último lugar, (i) como as crianças e os animais perseguem os prazeres e (ii) eles não são capazes de perseguir o bem que deve ser perseguido para o ser humano, isto seria um sinal de que o prazer não poderia ser um bem ou o bem supremo.

Em seguida, no capítulo 12, Aristóteles passa a refutar tais opiniões antihedonistas. A refutação da opinião de que o prazer não é um bem se baseia no argumento de que mesmo que o prazer seja um processo (genesis), ainda assim é um erro dizer que ele não é um bem. Com efeito, cometem tal erro aqueles que ignoram as seguintes distinções. Em primeiro lugar, assim como o bem tem um sentido duplo, i.e., absolutamente (haplôs) ou relativamente (tini), o seu contrário, o mal, também o terá. Em segundo lugar, as naturezas (phuseis) e as disposições (hexeis), quando aplicadas às categorias de bem ou de mal, estão abertas a esse duplo sentido, bem como os movimentos (kineseis) e os processos (geneseis). Isso porque os movimentos e os processos, por provirem de naturezas ou disposições particulares, também receberiam tais atributos.

É preciso, para o Estagirita, estabelecer certos matizes à concepção do prazer como um processo. Em primeiro lugar, alguns processos tidos como maus absolutamente, podem ser bons relativamente e de fato escolhidos por alguém. ${ }^{10} \mathrm{Em}$ segundo lugar, certos

${ }^{8}$ EN VII 11: 1152b16: empodion toi phronein hai hêdonai. Esta também parece ser uma concepção do diálogo Fedon (66c) de Platão, pois, o fato de os prazeres impedirem o pensamento, como aqueles próprios do estado apaixonado, justifica a tese de que seria um bem para alma se libertar do corpo.

${ }^{9}$ Este argumento parece se referir ao diálogo Górgias (462a-465d) de Platão, em que a retórica e outras habilidades como a de cozinhar não são consideradas verdadeiras artes (technai), pois não produzem um bem, mas apenas bens aparentes que servem para deleitar. Ver também Frede (2005, pg. 191).

${ }^{10}$ Aristóteles não nos fornece nenhum exemplo, mas poderíamos pensar em um remédio que, embora não seja em absoluto ou sem qualificações algo bom, ele certamente é bom para um paciente que o necessite em seu tratamento. Outro exemplo ainda mais esclarecedor é o ato de amputar uma parte do corpo, pois a amputação pode ser boa para um corpo doente no sentido de 
processos não são bons em absoluto, pois não são desejados em si mesmo, e nem relativamente, i.e., não são geralmente desejados por alguém, embora possam ser desejados por alguém, em certa circunstância, e por certo tempo. Por isso, o Estagirita nos diz que eles são maus em absoluto e, em geral, relativamente, mas não em determinada circunstância e por certo tempo. ${ }^{11}$ A diferença entre o primeiro caso e o segundo, é que no primeiro o processo pode ser regularmente bom para determinadas pessoas; já no segundo, o processo pode ser eventual e pontualmente bom para determinadas pessoas em situações extremas. Em terceiro e último lugar, alguns processos não são de modo algum bons e, portanto, não são realmente, mas apenas aparentemente prazerosos, pois são acompanhados de dor e são buscados como remédios para aliviarem a dor.

Com tais distinções, o filósofo refuta a tese de que o prazer não poderia ser considerado um bem, se fosse um processo ou movimento. O cerne da refutação encontrase no argumento de que o processo também pode ser considerado um bem, senão em absoluto, ao menos relativamente. Donde se conclui que dizer que o prazer é um processo não implica necessariamente dizer que ele não seja um bem, pois, mesmo que ele seja em absoluto um mal, ainda assim ele poderia ser relativamente um bem. Em suma, como acabamos de ver, a partir do duplo sentido de bem e mal - absoluto e relativo -, o filósofo refuta a tese de que o prazer deve ser tomado como um mal em absoluto se identificado a um processo.

Em seguida (1152b33-1153b8), depois de refutar a tese de que o prazer é o mal em absoluto, o filósofo pretende estabelecer em qual sentido o prazer pode ser um bem. Para tanto, é preciso antes conceber o que é o bem. Certamente, para que o prazer possa ser um bem, não poderá prevalecer a concepção de Platão de que ele é um processo de restauração (kathistasai) ao estado natural perfeito, estado em que não há carência ou

evitar o falecimento do indivíduo, mas ela não poderia ser boa para o corpo em sua perfeita condição de natureza, para o corpo enquanto tal, o corpo sadio. Neste sentido, o processo de amputação não poderia ser bom em termos absolutos.

11 Aristóteles tampouco nos oferece um exemplo que ilustraria uma situação deste tipo, mas poderíamos supor que, por exemplo, não é bom em absoluto comer algo que ninguém, por princípio, comeria, nem mesmo uma pessoa em particular, mas apenas em uma situação de extrema necessidade, como seria o caso em que é preciso comer carne humana para sobreviver quando não há outra fonte de alimento (Tomás de Aquino também exemplifica este caso com o ato de comer algo por extrema necessidade (1993, § 1485)). 
falta, ou seja, o prazer é um mero preenchimento de um vazio ou uma falta dolorosa, portanto intrinsecamente misturado com dor. ${ }^{12}$

A resposta a esta objeção de caráter platônico surge inesperadamente, sem justificativas ou pormenores aparentes. Aristóteles parte do pressuposto de que o bem é tanto uma atividade (energeia), como uma disposição (hexis). Com o intuito claro de refutar Platão, Aristóteles concebe o prazer não como um processo, mas como uma atividade ou uma atualização (energia) que pode acompanhar um processo. Neste caso, enquanto acompanhante de um processo, deve-se dizer que ele é acidental, e, enquanto uma atividade, que ele é real.

Segundo o filósofo, o prazer acidental é aquele que sentimos quando estamos em processo de restituição ou reabilitação de nosso estado natural. Por isso, devemos entender tal prazer como sendo concomitante (kata sumbebêkos) ao processo restaurador de nossa natureza (1152b34-35). Com efeito, um prazer sentido por alguém em estado de reabilitação não pode ser prazeroso em absoluto, sem qualificações (haplôs), ou por natureza (phusei) (1153a6). Por exemplo, ninguém sentiria prazer com algo extremamente acido ou amargo a não ser que esteja doente. Tampouco alguém sentiria prazer em se aquecer com uma manta em um ambiente quente, a não ser que se esteja febril. Por isso, este tipo de prazer só pode ser assim considerado apenas relativamente a alguém que esteja doente ou em estado de debilidade e não em termos absolutos, i.e., ele não pode ser dito naturalmente prazeroso, mas sim acidentalmente, ou melhor, concomitantemente ao processo de superação do estado de debilidade. Por isso, os prazeres que acompanham a convalescença não são em si mesmo prazerosos, mas apenas para aqueles que se encontram em tal estado.

Há, portanto, dois momentos distintos: um em que o estado de natureza está debilitado e o que é bom ou prazeroso diverge do que comumente se julga ser bom e prazeroso; e outro momento em que o estado é aquele em que a nossa natureza física e psíquica se encontra em sua perfeita condição e o julgamento sobre o que é bom e

${ }^{12}$ A definição do prazer como um mero preenchimento de uma falta dolorosa encontra-se no diálogo Górgias, 496c-500e. Também em Filebo, 31d-32a, o prazer impuro - misturado com a dor - consiste na reparação de um equilíbrio ou no preenchimento de uma falta. Os exemplos que Platão costuma usar são os processos de saciação da fome e da sede. Em MM II 7, Aristóteles faz referência explícita ao fato de que a concepção platônica do prazer como um processo sensível, portanto, corporal, implica pressupor que o prazer surge da dor por um excesso ou falta no corpo, pois, "como a falta e o excesso são penosos; então, onde o prazer surge há dor" (1204b12). Ver também o texto em que Dorothea Frede descreve as várias concepções de prazer nos diálogos de Platão (2009, pg. 236-253). 
prazeroso pode expressar o bem e o prazer por natureza. Ou seja, uma pessoa virtuosa e saudável certamente encontra seus prazeres no que é, por natureza, prazeroso. Como nos diz o filósofo:

Uma indicação de que o prazer é acidental é que nós não fruímos das mesmas coisas quando nosso estado natural está em processo de reabilitação como quando já está reabilitado. Neste último caso, fruímos de coisas que são prazerosas em absoluto; mas durante a reabilitação, fruímos até mesmo de seus contrários. Por exemplo, o ácido e o amargo não são nem por natureza nem absolutamente prazerosos, tampouco são os prazeres por tais coisas (EN VII 12: 1153a3-6). ${ }^{13}$

Como define Aristóteles, o prazer natural é próprio da "atividade dos apetites que pertence à disposição e à natureza que permaneceram preservadas” (1152b35-36). Com efeito, sentimos prazer quando atualizamos nossas potencialidades naturais, sejam elas vegetativas, perceptivas ou intelectivas, i.e., quando exercemos atividades próprias à nossa natureza em estado de não debilidade ou carência física (como uma doença), ou psicológica (como uma loucura, bebedeira ou outro estado de perturbação psíquica) (tês phuseôs ouk endeô̂s ousês) (1153a2); mesmo que tal natureza seja apenas uma parte ainda saudável em um indivíduo convalescente. Ou seja, mesmo em um estado de debilidade, o prazer que sentimos é próprio da atividade do que permaneceu saudável e apenas concomitante ao processo de reabilitação, portanto, podemos dizer que tais prazeres acidentais são restauradores. Nas palavras do filósofo:

Os prazeres sem dor não admitem excesso. E tais prazeres são por natureza e não por acidente. Chamo de prazeres por acidente aqueles que são restauradores (ta iatreuonta). Isso porque o ato de restaurar ocorre por meio da ação do que permaneceu saudável; por isso <o processo> parece ser prazeroso. Assim, o prazer por natureza é aquele que produz uma ação de uma natureza <saudável> (EN VII 14: 1154b16-21).

Isso significa que o prazer é sempre uma atividade ou atualização do que há em nós de saudável ou perfeitamente natural; todavia, ou estamos plenamente saudáveis de modo que o prazer será simplesmente natural, ou estamos doentes e o prazer será tanto uma atividade conforme o que nos resta de saúde, como um concomitante de um processo de convalescença. Neste último caso, ele pode ser dito tanto natural, como acidental ou concomitante.

Desse modo, o prazer que ocorre concomitantemente à convalescença não pode ser identificado ao processo de convalescer. Tampouco poderíamos reduzir todo prazer à categoria de acidental. Afinal, há prazeres absolutamente naturais e há prazeres que são

${ }^{13}$ Todas as traduções são de minha autoria. 
tanto naturais como acidentais. Não há prazer que seja apenas acidental. Durante a convalescença, a parte saudável entra em atividade e é acompanhada de um prazer próprio ao seu exercício e não acidental a ele. Nas palavras do filósofo:

Com efeito, os prazeres não são processos (geneseis), nem todos ocorrem junto a processos: eles são atividades (energeiai), i.e., fins (telos). Tampouco eles surgem quando estamos nos tornando algo, mas quando estamos exercitando alguma faculdade. E nem todo prazer tem um fim distinto dele mesmo, mas apenas aquele de quem está se direcionando para a perfeição de sua natureza $(1153 \mathrm{a} 10-13){ }^{14}$

Podemos interpretar o trecho acima do seguinte modo: no convalescente, o prazer tem outra finalidade que não ele mesmo: a de aliviar a dor; enquanto no saudável, a finalidade é o próprio ato de ter prazer quando se atualizar qualquer faculdade ou capacidade, i.e., ao exercer qualquer que seja a atividade, desde que ela seja saudável. Por isso, a afirmação de que o convalescer é prazeroso pode ser enganadora. Ora, se o próprio convalescer fosse prazeroso, todos nós quereríamos naturalmente adoecer, o que não é o caso. Todavia, como é inegável que temos prazer durante a convalescença, Aristóteles se põe a explicar que tal prazer não é o próprio processo de convalescer, mas sim a atividade que permaneceu saudável no organismo e que, enquanto acompanhante de tal processo, ele é acidental.

Por exemplo, quando dizermos que 'um músico fez esta estátua', devemos entender que ele a fez não enquanto músico, mas enquanto escultor. Para expressarmos em termos aristotélicos esta explicação, deveríamos dizer que "um músico fez acidentalmente esta estátua", compreendendo acidentalmente como não sendo próprio da natureza de $A$ fazer $B$, i.e., não é próprio da natureza do músico fazer esculturas. Dizer que não é próprio da natureza de $A$ fazer $B$ não é o mesmo que dizer que é eventual ou excepcional à sua natureza (este também é um dos sentidos de "por acidente"). ${ }^{15}$ Analogamente, se dizemos que "o convalescer é acidentalmente prazeroso", devemos

${ }^{14}$ Quanto ao trecho all'energeiai kai telos, cabe sinalizar que compreendemos o kai desta frase como expletivo e o traduzimos como isto é. Isso porque o prazer é identificado com a atividade e ela é o seu próprio fim, ao contrário do processo, cujo fim lhe é extrínseco. Cabe notarmos que, no segundo Tratado, a definição de prazer também será a de um fim ou perfeição ( $t i$ telos), portanto, uma atividade, visto que energeia e telos são o mesmo. Mais uma vez, podemos dizer que há um compartilhamento de conceitos nos dois Tratados, mesmo no que diz respeito à definição de prazer: em ambos os Tratados, o prazer é uma atividade.

15 Ver Met. V 30 e VI 2 sobre os dois sentidos de kata sumbebêkos (como ocorrendo excepcionalmente ou como não sendo por natureza); já para saber mais de sua aplicação para a interpretação do prazer acidental, ver Owen (Owen, G.E.L., 2010, pg. 93-94). 
entender acidentalmente como não sendo próprio da natureza do convalescer ser prazeroso ou que não é enquanto um convalescer que este processo é prazeroso. Enfim, os argumentos do Estagirita, como vimos, nos conduzem à seguinte conclusão: se o prazer não é um processo, então ele é uma atividade. Se ele é uma atividade, então ele é um fim em si mesmo, uma perfeição, um acabamento (telos), e não um processo cuja natureza é inacabada e cujo fim lhe é extrínseco. Nesse sentido, ele pode ser considerado um bem em termos absolutos e não apenas relativa e acidentalmente.

Em resumo, vimos até o momento, que o prazer que acompanha um processo (genesis) ou movimento (kinêsis) de restauração, como a convalescença, deve ser entendido como acidental. Esse prazer não é ele mesmo um processo, mas uma atividade. Em poucas palavras: a diferença entre o prazer acidental e o natural seria que o primeiro é uma atividade que acompanha um processo "restaurador (kathistâsai) do estado de natureza" (1152b34), enquanto o segundo é uma atividade própria ao estado de perfeita saúde.

Isso significa dizer que, ao contrário do que acreditava Platão, o processo não pode ser essencialmente prazeroso, mas apenas acidentalmente por ocorrer em concomitância a certos prazeres. É evidente que, aos olhos do Estagirita, a natureza do prazer não poderia ser definida pelo que lhe é acidental, e, por isso mesmo, Aristóteles fornece a sua definição de prazer corrigindo a de Platão ${ }^{16}$ :

Portanto, não é correto dizer que o prazer é um processo sensível, mas antes é preciso dizer que ele é uma atividade do estado natural (energeian tês kata phusin hexeôs) e substituir 'sensível' (aisthêtên) por 'desimpedida' (anempodiston) (1153a13-15). ${ }^{17}$

Com tal definição, o Estagirita finaliza sua refutação da concepção platônica de prazer como um processo sensível de preenchimento de uma falta dolorosa, falta esta própria a um estado de carência ou de privação. Aos olhos do filósofo, duas substituições devem ser feitas: em primeiro lugar, o prazer não é um processo, mas uma atividade, ou seja, ele não é um restaurador do estado de natureza, mas a realização de uma atividade própria a tal estado. Em segundo lugar, ele é desimpedido e não sensível, visto que qualquer atividade, sensível ou intelectiva, pode ser prazerosa e não apenas sensível. Logo, a condição para ser prazerosa não é que a atividade seja sensível, mas que ela seja

${ }^{16}$ Cf. Filebo 33c-e e 51b. Ver também Frede (2005, pg. 196).

${ }^{17}$ A definição se repete no capítulo seguinte, em 1153b12. 
desimpedida, visto que qualquer impedimento ao seu exercício também obliteraria a fruição do prazer e seria sempre sentido como penoso. ${ }^{18}$

Depois de ter refutado, no capítulo 12, as opiniões que negam a possibilidade de o prazer ser um bem e estabelecer que ele é um bem por ser uma atividade e não um processo, Aristóteles, no capítulo seguinte, pretende refutar àqueles que dizem que o prazer não poderia ser o bem supremo e acaba, como veremos, assumindo, de modo hipotético ou dialético, uma tese hedonista radical - a de que o bem supremo poderia ser um prazer - a titulo de refutação ao anti-hedonismo.

O capítulo 13 inicia-se com a exposição de uma espécie de disputa entre dois argumentos contrários: um argumento hedonista atribuído a Eudoxo ${ }^{19}$, e outro antihedonista atribuído a Espeusipo (1153b1-7). O argumento de Eudoxo é o seguinte: o prazer é um bem (agathon ti), já que todos concordam que o seu oposto, a dor, é um mal. A refutação de Espeusipo inicia-se com a afirmação que são dois os opostos do maior: o menor e o igual. Analogamente, ainda que a dor seja um mal, o oposto da dor pode ser tanto o prazer, como um estado neutro: nem doloroso, nem prazeroso. Por isso, que o prazer seja oposto à dor não decorre necessariamente que ele seja um bem, pois o estado neutro, também ele oposto à dor, pode ser um bem. Com efeito, Espeusipo parece ter afirmado que a felicidade consiste em uma vida neutra, livre de perturbações advindas do prazer e da dor. ${ }^{20} \mathrm{O}$ bem, portanto, estaria localizado entre dois males: a dor e o prazer, e deveria ser um estado de neutralidade ou tranquilidade.

${ }^{18}$ Cf. EN VII 13: 1153b2-3. Outro trecho nos fornece explicitamente o que seriam alguns impedimentos (empodioi): "como nenhuma atividade impedida é perfeita e a felicidade é uma atividade perfeita, o homem feliz necessita de bens do corpo, externos e da fortuna (tuchês), de modo que ele não seja impedido por eles" (EN VII 13: 1153b17-19). Nesse sentido, o impedimento seria ou corporal ou extrínseco à própria realização da atividade. Riel, por sua vez, compreende que o impedimento pode ocorrer tanto por parte do objeto como do sujeito; logo, o desimpedimento é a conjunção da faculdade e de seu respectivo objeto quando ambos se encontram em perfeitas condições. O exemplo que ele fornece é o seguinte: "Quando meu ouvido, por exemplo, ouve belos sons de modo perfeito, sua atividade de ouvir frui um prazer específico (e o mesmo para as outras faculdades). Ouvir, por sua vez, perfeitamente sons desagradáveis não é prazeroso, tampouco o é ouvir de modo imperfeito belos sons (tradução minha)" (RIEL, 2000, pg. 51).

${ }^{19}$ A atribuição é explicitada apenas em $E N$ X 2: 1172b18-20.

${ }^{20}$ Segundo Clemente de Alexandria, Espeusipo dizia que os homens bons visam à ausência de perturbação (aochlêsias) (Stromata II 22). Sobre tal referência, ver Rapp, 2005, pg. 211. Em EN II 3, depois de ter mostrado que o modo indevido de buscar e evitar os prazeres e as dores tornam os homens torpes, Aristóteles, provavelmente fazendo referência a Espeusipo, diz que "é por isso que também definem as virtudes como certas impassibilidades e quietudes" (1104b24-25), criticando-o em seguida. 
Todavia, mesmo que Espeusipo assuma que o prazer seja um mal, ainda assim, o Estagirita supõe que, por mais anti-hedonista que seja sua opinião, ele não poderia assumir que o prazer seja essencialmente ou intrinsicamente um mal (hoper kakon ti). De fato, parece no mínimo estranho ou um contrassenso assumir que aquilo que todos buscam seja essencialmente um mal. É possível que nem mesmo Espeusipo o concebesse como um mal per se, pois o prazer seria ruim não em si mesmo, mas na medida em que causasse perturbações. ${ }^{21}$ De todo modo, a explicação de Espeusipo não se sustentaria diante do julgo de Aristóteles, pois "é evidente que os homens evitam a dor como um mal e buscam o prazer como um bem; logo, prazer e dor são antípodas" (EN X 2: 1173a1213). Não haveria, pois, uma dupla oposição do prazer em relação à dor e ao estado neutro, mas apenas uma oposição de mão dupla: prazer versus dor.

Em seguida (1153b7-13), depois de ter demonstrado que o argumento de Espeusipo é falho e que, portanto, a visão hedonista parece estar mais próxima da verdade, o filósofo passa a refutar a opinião anti-hedonista de que o prazer não poderia ser o bem supremo. Sabemos que, no livro primeiro da Ética Nicomaqueia, ele critica explicitamente a opinião da maioria que crê que a vida prazerosa é a vida feliz. Embora o prazer não seja o bem supremo, certamente ele não deixaria de ser uma das causas necessárias da felicidade (eudaimonia). Por isso, Aristóteles não passará a defender que um tipo de prazer pudesse ser o bem supremo, senão a título de refutação. Entendo, com isso, que ele não assumirá como tese própria, mas adotará a hipótese de que o bem supremo poderia ser um certo prazer, mesmo que a maior parte dos prazeres seja ruim, tendo em vista única e exclusivamente refutar a concepção anti-hedonista que diz exatamente o contrário.

Para defender tal hipótese, o filósofo faz uso de dois argumentos. O primeiro afirma que certo prazer poderia ser o bem supremo (1153b7-24) e o segundo que o prazer é, em certo sentido, o bem supremo (1153b25-32). O primeiro pode ser resumido no que se segue: mesmo havendo prazeres ruins, nada impede a possibilidade (ouden kôluei: $1153 \mathrm{~b} 7)^{22}$ de que um certo prazer seja o bem supremo. Do mesmo modo, o fato de haver certos conhecimentos ruins não impede que um possa ser o melhor dentre todos. Visto que nada impede tal possibilidade, a conclusão é obtida a partir de duas premissas

${ }^{21}$ Quanto a este ponto, não podemos formular senão conjecturas. Para saber mais, veja Rapp, 2005, pg. 213-214.

22 "ouden kôluei" parece indicar a possibilidade lógica da conclusão se seguir, como bem assinalou RAPP, 2005, pg. 215. 
verdadeiras, a saber: (i) visto que cada disposição (hexis) exerce suas atividades sem impedimentos e a eudaimonia é uma atividade desimpedida de todas ou de uma disposição, a saber, a mais desejável; e (ii) como toda atividade desimpedida é prazerosa $^{23}$, logo, (iii) o bem supremo seria um certo prazer (eiê an tis hêdonê to ariston).

A conclusão de que um tipo de prazer seria o bem supremo levou diversos comentadores a procurarem uma solução para o dilema posto, a ponto de Christof Rapp ${ }^{24}$, fazendo um balanço das muitas e díspares interpretações, denominar tal tese de chocante - the shocking thesis. A minha interpretação, por sua vez, concorda com a de Aspásio ${ }^{25}$, pois tal argumento parece ser exclusivamente dialético. Aspásio, em seu comentário à Ética Nicomaqueia (150.31-152.3), diz que, se o primeiro Tratado for de fato de Aristóteles, o argumento é dialético, ad hominem $(151.21,26)$ e, possivelmente, ad personam Speusippi.

Isso significa que a afirmação de que certo prazer seria o bem supremo tem um efeito meramente refutativo, portanto, dialético. Certamente, Aristóteles não pretenderia se contradizer assumindo tal tese. Há algumas indicações linguísticas que apontam para esta interpretação, como o uso da forma verbal seria (eiê an: 1153b13) que atenua a atribuição do predicado (certo prazer: tis hêdonê) ao sujeito (bem supremo: to ariston) e do advérbio em certo sentido ( $p \hat{s} s$ ) contido na seguinte frase mais adiante no texto: "Que todos os animais e todos os seres humanos perseguem o prazer é um sinal de que ele, em certo sentido (pôs), é o bem supremo" (1153b25-28).

Outros comentadores, como Owen ${ }^{26}$ e Charles $^{27}$, pretendem solucionar tal dilema negando que o filósofo tenha definido o prazer como uma atividade. Owen, por exemplo, diz que o objeto do primeiro Tratado não é a atividade prazerosa, mas as coisas prazerosas; ou seja, não é o prazer, mas o prazeroso que deve ser entendido como uma atividade, pois são as atividades desimpedidas que nos dão prazer. Com esta interpretação, de fato, a contradição desapareceria, pois a felicidade é realmente uma atividade desimpedida que nos dá prazer, i.e., a felicidade não seria o prazer, mas o objeto de prazer. Afinal, a vida feliz "é prazerosa em si mesma" (EN I 8: 1099a10-16).

${ }^{23}$ Para compreender tal estratégia argumentativa, é importante ter em mente que o prazer acabou de ser definido como uma atividade desimpedida (1153a14-15).

\footnotetext{
${ }^{24}$ Rapp, 2005, pg. 218-220.

${ }^{25}$ Aspásio, 2006, 150, 18-24.

${ }^{26}$ Owen, G.E.L., 1977.

${ }^{27}$ Charles, D., 1986.
} 
Certamente, dizer que a felicidade é prazerosa é bem distinto de dizer que ela é um tipo de prazer.

O problema é que Aristóteles, a meu ver, não está preocupado em definir simplesmente o objeto prazeroso, mas sim o próprio prazer. E o prazer nada mais é do que as atividades prazerosas, i.e., as atividades ou atualizações de nossas capacidades anímicas e físicas, havendo ou não objeto externo que cause prazer. Com efeito, como a investigação do primeiro Tratado tem como objetivo apreender a natureza do prazer de modo a garantir que o prazer possa ser um bem, é plausível que Aristóteles não esteja simplesmente definindo o objeto prazeroso. Mesmo porque o valor moral do prazer não se reduz à natureza do seu objeto, visto que podemos ter prazer com bons objetos, mas desejá-los excessivamente, o que torna o prazer ruim.

Charles, por sua vez, diz que o termo atividade (energeia) é ambíguo e pode querer dizer tanto o exercício como o resultado da atividade, sendo que o prazer deve ser entendido antes como resultado do que como o próprio exercício da atividade. Ora, a ambiguidade de um termo não poderia por si só sustentar uma interpretação ou refutar a sua contrária, mesmo porque, por sua ambiguidade, ela dá indícios a favor tanto de uma como de outra. A concepção de prazer como resultado da atividade, a meu ver, só foi formulada no segundo Tratado, não podendo, portanto, ser apropriada para a definição de prazer do primeiro Tratado.

Segundo Rapp, não há problema algum em identificar a felicidade com um tipo de prazer, visto que cada atividade tem o seu prazer próprio, como fica claro com a tese da diferença específica dos prazeres do livro X. Isso significa que tudo o que Aristóteles queria dizer é que um tipo de prazer é constitutivo da felicidade, mas não é a própria felicidade; pois há uma predicação extensional, mas não identitária entre os sujeitos: felicidade e prazer. O ponto problemático desta intepretação é que, no primeiro Tratado, esta condição de que o prazer é sempre uma atividade que acompanha outra não fora elaborada; logo, no primeiro Tratado, a predicação é sempre identitária com a atividade exercida, enquanto no segundo, é sempre extensional. Cabe fazer a ressalva que a identidade é apenas hipotética e não real. Podemos, inclusive, especular que tal condição foi elaborada no segundo Tratado justamente para dar conta desta armadilha que o filósofo coloca a si mesmo neste momento. Ademais, a pergunta que fica pendente, já que Rapp não responde, é a de saber qual é este tipo de prazer. Tomás de Aquino, como veremos, responde à pergunta sem hesitação: tal prazer só pode ser o contemplativo. 
Visto que algum prazer poderia até ser considerado o bem supremo, Aristóteles nos diz em seguida que, neste sentido, nós podemos compreender por que todos "incluem o prazer na felicidade": "é por essa razão que todos pensam que a vida feliz é prazerosa e incluem o prazer na felicidade, e com boas razões, já que nenhuma atividade impedida é perfeita, e a felicidade é perfeita" (EN VII 13: 1153b14-17). Esta opinião geralmente aceita e já referida em outras passagens da Ética Nicomaqueia ${ }^{28}$ não postula a identificação da felicidade a um tipo de prazer, pois o que todos pensam é que a vida feliz é prazerosa (hêdun) e não que ela seja um tipo de prazer (tina hêdonên). Por isso, com boas razões, todos incluem (emplekousi) o prazer na vida feliz. Certamente, Aristóteles concorda com a inclusão do prazer na vida feliz, pois, segundo o mesmo, a vida feliz é em si mesma prazerosa.

A razão pela qual a vida feliz é necessariamente prazerosa é que ela é uma atividade perfeita (teleios), portanto, desimpedida; e toda atividade desimpedida é prazerosa. Ou seja, como a felicidade é perfeita, a sua realização não poderia ser impedida pela falta de certos bens externos, pois um impedimento à sua realização implicaria a sua imperfeição. Afirmar que é preciso exercer de modo desimpedido a felicidade corrobora com a tese que nega a possibilidade de a disposição virtuosa ser, sob quaisquer circunstâncias, a causa suficiente da felicidade. Ora, mesmo o virtuoso certamente depende de bens externos para viver bem. A falta desses bens pode se constituir como fator impedidor à realização da atividade perfeita. Os fatores impedidores que são extrínsecos à disposição e ao desejo do agente virtuoso podem ser entendidos, segundo o filósofo, como as adversidades corporais e materiais. Um exemplo extremo que costuma nos fornecer o filósofo é que não seria feliz aquele que, mesmo sendo bom, sofresse grandes e intensas vicissitudes. Porém, não estando em falta os bens do corpo e os da fortuna, a atividade é exercida desimpedidamente.

Ademais, com relação à boa fortuna (eutuchia), podemos compreender como sendo tanto bens externos materiais, como a riqueza, o poder político, os amigos e os filhos; como também a boa sorte, pois é matéria de sorte (tuchê) ser herdeiro de riquezas, ter boa estirpe, beleza etc. ${ }^{29} \mathrm{O}$ filósofo ressalta que, apesar de a boa fortuna ser necessária para a felicidade, não se poderia identificá-la com a felicidade, mas antes a primeira deve

${ }^{28}$ Como, por exemplo, em I 9: 1098b25.

${ }^{29}$ Cf. EN I 8: 1099a29-b8. Ver também Ret. II 12: 1389a1. Em Retórica I 5, boa fortuna consiste em "obter e manter as boas coisas, cuja causa é a sorte (tuchê), senão todas, a maioria ou as mais importantes" (1361b39-1362a1). 
ser definida em relação à segunda. Tanto a ausência como o excesso de fortuna, conclui Aristóteles, são impedidores da felicidade. Isso significa que a fortuna moderada é necessária, mas, quando excessiva, pode atrapalhar por induzir aquele que a possui em excesso à insensatez e arrogância. ${ }^{30}$

Em seguida, Aristóteles fornece seu segundo argumento quanto à possibilidade de um prazer ser o bem supremo (1153b25-32). O argumento, à primeira vista, parece ser dialético, entendendo dialético como um argumento que assume a opinião da maioria ou dos mais sábios como um objeto a ser examinado, pois que guardaria algo de verdadeiro. $\mathrm{O}$ argumento se justifica a partir da tese de que aquilo com o qual todos concordam não pode ser inteiramente falso, a saber: "Que todos os animais e todos os seres humanos perseguem o prazer é um sinal de que ele é, em certo sentido (pôs), o bem supremo" (EN VII 13: 1153b25-28). Trata-se de um consenso, como parece indicar a citação de Hesíodo que o Estagirita utiliza para mostrar que há algo de verdadeiro no argumento, a saber: "a voz de muitos não é inteiramente insignificante" (Trabalhos e Dias: 173). A passagem análoga a esta, presente no livro X, cujo objetivo é refutar o anti-hedonismo de Espeusipo, parece ser ainda mais explicativa:

Aqueles que negam que aquilo que todos buscam seja um bem certamente falam coisas sem sentido. Isso porque dizemos que aquilo que todos pensam assim é. E aquele que rechaça essa crença dificilmente dirá outra mais persuasiva. Se apenas seres irracionais desejassem obter o que é prazeroso, haveria algum sentido no que dizem; mas na medida em que seres inteligentes também o fazem, que sentido teria tal objeção? Talvez até mesmo animais inferiores possuam

${ }^{30}$ Parece ser evidente que a ausência de fortuna ou sorte (tuchê) impede a realização da própria felicidade (eudaimonia), como vemos em EN I 9 (1099b9-1100a9). Quanto ao excesso de fortuna, poderíamos supor que ele possa ser prejudicial se nos induzir a negligenciar a aquisição e a preservação da virtude. Agora, se de fato seria prejudicial não é claro e o filósofo não desenvolve essa questão. Todavia, é razoável supor que aquela pessoa que não passasse por nenhuma adversidade não poderia desenvolver certas disposições necessárias para ser um homem bom e, consequentemente, feliz. É possível que o excesso de riqueza o impeça de saber lidar com as dores adequadamente, na medida em que não lança o agente em circunstâncias desfavoráveis que lhe obriguem a enfrentar certas dores em vista de agir virtuosamente. Em Ret. II 17: 1391a33-b1, o filósofo sinaliza tal dificuldade ao nos dizer que a maior parte daqueles que usufruem de boa fortuna é arrogante e insensata. Para o filósofo, o ideal é ter moderada fortuna: "Ainda que não se possa ser feliz sem bens exteriores, não devemos pensar que aquele que há de ser feliz precisará de muitas e grandes coisas; pois a autossuficiência e a ação moral não requerem tais bens em excesso. É possível realizar boas ações sem ter de dominar a terra e o mar. Com efeito, mesmo com recursos moderados, alguém pode agir virtuosamente (isto é manifesto, considerando-se que simples indivíduos levam a cabo ações valiosas tanto quanto os poderosos, ou até mais); basta dispor de bens exteriores nesta medida, pois será feliz a vida que atue de acordo com a virtude. Sólon também, provavelmente, compreendeu bem o homem feliz ao descrevê-lo, segundo o que pensava, como aquele que, moderadamente provido de bens exteriores, havia praticado as mais belas ações e vivido de modo temperante; porque se pode, com bens moderados, praticar o que se deve" (EN X 8: 1179a1-12). 
algo natural mais forte do que eles mesmos que busca o seu bem próprio (ephietai tô̂ oikeiou agathoû) (EN X 2: 1172b36-1173a5).

Neste momento, no livro $\mathrm{X}$, em que o mesmo argumento é usado para refutar o anti-hedonismo, ele não parece ser mais de cunho dialético, mas sim cientifico. Ou seja, a expressão de que todos os seres buscam o prazer não parece ser fruto apenas de um consenso, mas antes da observação do comportamento dos animais irracionais e racionais. Isso porque a busca de prazer se traduz pela busca natural do bem próprio, o que é comum a todos os seres por causa de um princípio interno natural que os impele a buscar o seu bem próprio. Tal princípio que Aristóteles chama de divino no livro VII (1153b32) é o mesmo referido no livro $X$, como vimos na citação acima: "até mesmo animais inferiores possuem algo natural mais forte do que eles mesmos, que busca o seu bem próprio". Certamente, o bem para cada ser varia conforme sua natureza, mas há algo em comum para todos os homens e animais, a saber: todos buscam o prazer na medida em que buscam o seu bem próprio. Seria contra intuitivo afirmar que aquilo a que todos buscam seja um mal para si, pois, se a natureza faz com que todos os animais persigam o prazer, então não poderíamos dizer que a natureza erra por inteiro ou na maior parte dos casos. Assim, a explicação do argumento parece ser antes de cunho biológico ou naturalista no livro X do que dialético. Se todos os animais buscam o prazer, parece ser mais do que legítimo afirmar que o prazer possa ser necessariamente um bem, ou até mesmo o bem supremo em algum sentido.

Este segundo argumento seria decisivo para atribuir ao prazer o estatuto de bem supremo, se não fosse pela expressão adverbial "em certo sentido" (pôs: 1153b27), que atenua a afirmação identitária. É possível conceber dois sentidos para o advérbio pôs: um material e outro formal. Segundo a interpretação material do advérbio, nem todo prazer, mas somente um tipo seria o bem supremo, ou seja, "certo prazer é o bem supremo". Como inferiu Tomás de Aquino, este tipo de prazer seria o contemplativo. Segundo a interpretação formal, o prazer não é absolutamente o bem supremo, mas apenas em certo sentido, i.e., conforme certa inferência hipotética, a saber: se o prazer é uma atividade desimpedida, assim como a felicidade, isso significa que o prazer seria, enquanto atividade desimpedida, identificável à felicidade. Ou seja, o prazer seria um atributo próprio à natureza da felicidade e não a sua própria natureza, visto que esta não é a definição de felicidade. Isso indica que a atenuação não seja gratuita, e, mais ainda, que a interpretação formal do advérbio seja mais razoável, na medida em que a felicidade não é concebida como um tipo de prazer, i.e., como um tipo de atividade desimpedida do 
nosso estado natural, mas antes como uma atividade segundo perfeita virtude que também possui o atributo de ser desimpedida, portanto prazerosa.

Com efeito, o atributo ser desimpedida e, consequentemente, prazerosa, por sua vez, não expressa a definição de felicidade, mas é antes uma propriedade que decorre de sua definição. Ou seja, é por ela ser uma atividade segundo perfeita virtude que ela também deve ser uma atividade desimpedida e prazerosa. O prazer é antes o efeito e não a causa do desimpedimento. Por isso, assim como interpreta Alexandre de Afrodisia, a felicidade é prazerosa porque ela é realizada conforme a virtude. Ser prazerosa é uma decorrência necessária de sua essência, é um atributo próprio da felicidade, mas não a define enquanto tal.

Segundo Alexandre de Afrodisia, não é o prazer, mas a virtude a principal causa de certa atividade ser desimpedida, pois viver conforme a virtude tem como consequência a ausência de certos impedimentos, pelo menos os impedimentos oriundos da disposição e do comportamento morais do agente. Como a vida feliz é aquela vivida segundo a virtude e não segundo o prazer, a virtude é, em grande parte, a causa de o homem realizar as atividades próprias à sua natureza e de realizá-las de modo desimpedido, visto que o vício ou a falta de regramento quanto aos próprios desejos e emoções impediriam a fruição de uma vida feliz. ${ }^{31}$

Digo em grande parte, uma vez que a boa fortuna (eutuchia) também contribuirá para a livre fruição da felicidade. Há, como podemos notar, dois tipos de impedimento: um intrínseco à própria disposição moral do agente, i.e., se o indivíduo é virtuoso ou não, pois está em seu poder vir a ser ou deixar de ser virtuoso conforme a regularidade das ações que pratica, e outro extrínseco ao agente, pois não está ou está parcialmente em seu poder ter ou não ter boa fortuna. Se a boa fortuna deve ser entendida como bens do corpo, bens materiais e sorte, então, digamos que os bens do corpo estão parcialmente sob o poder do agente, uma vez que o mesmo pode se cuidar para manter a boa saúde física, mas também pode ocorrer de ele contrair um vírus ou bactéria ou sofrer alguma doença imprevisível. Do mesmo modo, os bens materiais estão parcialmente no poder do agente, visto que é preciso trabalhar ou exercer alguma atividade remunerada para obtê-los, mas nem toda sociedade fornece oportunidade de trabalho igualmente para todos os seus membros. Quanto mais desigual for a sociedade, menos estará no poder do agente

${ }^{31}$ Ver Alexandre de Afrodísia, Problema 23: 143,13-25, em Ethical Problems, trad. Sharpes, ed. Cornell University Press, Ithaca, New York, 1990, p. 57. 
conquistar seus próprios bens materiais. Quanto à sorte, i.e., certos acidentes e desastres, por sua natureza absolutamente contingente, não haveria dúvida de que ela não está de modo algum sob o poder do agente. É preciso, bem sabemos, contar com certa dose de sorte para que não haja impedimento do bem viver.

Contrariamente ao que foi dito, Tomás de Aquino supõe que a identidade entre prazer e bem supremo se explica se interpretarmos que Aristóteles estaria se referindo a um tipo determinado de prazer e não a qualquer um que seja. Tomás de Aquino entende que, a partir da frase - "talvez eles não persigam o prazer que eles pensam e dizem que perseguem, embora persigam o mesmo prazer (tên autên)" (1153b30-1) -, poder-se-ia concluir que todos, por natureza, buscam o mesmo prazer; ainda que, por ignorância ou julgamento incorreto, pensem e digam que buscam outros prazeres. Isso porque, segundo Tomás de Aquino, a natureza nos colocou algo de divino, i.e., uma inclinação natural em desejar conhecer. Desse modo, todos estão inclinados por natureza a desejar o mesmo prazer enquanto o mais supremo, a saber, o prazer da contemplação. ${ }^{32} \mathrm{O}$ erro, segundo o autor, consiste em supor, como faz a maioria, que o prazer corporal é o bem supremo. Certamente, tal suposição se deve ao fato de ele ser o tipo de prazer mais compartilhado por todos, mais perceptível e conhecido, na medida em que envolve coisas necessárias da vida.

Há dois problemas evidentes na interpretação de Tomás de Aquino. O primeiro é que Aristóteles parece estar se referindo ao prazer que todos, incluindo os animais irracionais, perseguem (1153b26). Como os animais não são capazes de contemplar, o prazer contemplativo não poderia ser aquele ao qual todos os seres buscam. O segundo problema é que a frase é ambígua, pois não sabemos ao que se refere o mesmo prazer (tên autên) que todos perseguem. Certamente, trata-se do mesmo tipo de prazer, mas não que este seja necessariamente o contemplativo, como interpretou Tomás de Aquino.

O tipo de prazer que seria o mesmo para todos, a meu ver, é justamente aquele que é bom em absoluto (haplôs) ou por natureza (phusei). É justamente aquele que todo animal sente ao realizar o seu bem próprio. O bem próprio varia conforme cada espécie,

32 A interpretação de Tomás de Aquino (1993, § 1511) poderia ser reforçada se fosse assumidamente uma tese aristotélica a de que a vida feliz é a vida contemplativa. Não examinaremos em detalhe esse ponto; mesmo assim, gostaríamos apenas de ressalvar que, em EN X7, não se afirma a identidade entre o prazer contemplativo e a felicidade, mas entre a atividade contemplativa e um tipo de felicidade, a saber, a mais perfeita. Logo, a identidade se produz entre a atividade contemplativa e a felicidade perfeita, e não entre o prazer da atividade contemplativa e a felicidade em geral. 
mas o prazer que lhe acompanha é essencialmente o mesmo, a saber: um prazer natural, i.e., uma atividade desimpedida conforme a natureza de cada ser. Ademais, se o prazer contemplativo fosse o bem supremo, Aristóteles não poderia ter afirmado linhas acima que até mesmo a contemplação (theôrein) pode ser nociva se excessiva (1153a19-21).

Por fim, depois de ter formulado a hipótese de que certo prazer poderia até ser o bem supremo, Aristóteles conclui o capítulo demonstrando, mais uma vez, que o prazer é um bem, visto que a negação desta concepção produz inconsistências (1154a1-7). Assim, por via negativa, chega-se à conclusão de que a vida feliz é necessariamente prazerosa. $\mathrm{O}$ argumento se sustenta a partir da refutação de três inconsistências. A primeira delas é a seguinte: (i) se o prazer, i.e., a atividade prazerosa, não for um bem, então (ii) o homem feliz não viverá prazerosamente, o que é incongruente. A segunda mostra que (i) se o prazer não fosse bom, tampouco ele seria necessário ao homem feliz; porém, (ii) como o prazer é necessário à felicidade, então ele deve ser um bem. A terceira refutação consiste em dizer que (i) se o prazer não fosse nem bom, nem mau, (ii) também a dor, sendo o seu contrário, não seria nem boa, nem má, e não teria porque evitá-la; logo, (iii) a vida do homem feliz poderia ser penosa, ou não seria mais prazerosa do que a dos outros homens, o que é evidentemente falso. Desse modo, o Estagirita conclui o capítulo 13 do livro VII com a tese de que o prazer pode necessariamente ser um bem, caso contrário, a vida virtuosa não seria em si mesma prazerosa e poderia ser evitada como se fosse penosa.

Como o intuito do presente texto não é fazer uma análise minuciosa de todo o primeiro Tratado do prazer, mas apenas evidenciar a primeira definição de prazer e os problemas que dela decorrem, podemos concluir dizendo que a concepção do prazer como uma atividade desimpedida do estado natural implica necessariamente a hipótese de identificação do prazer à felicidade, o que, como vimos, não parece condizer com o propósito do filósofo. Deste modo, esta primeira definição funcionaria antes como uma resposta à concepção platônica de que o prazer seria um processo sensível restaurador do estado natural do que propriamente algo que funcione bem na estrutura conceitual da Ética Nicomaqueia.

Podemos, resumidamente, concluir o seguinte do que fora argumentado. Em primeiro lugar, ele parece ser antes refutativo do que propositivo, ou seja, Aristóteles está antes preocupado em mostrar o quão inconsistentes são as opiniões anti-hedonistas, sobretudo as de Espeusipo e de Platão, que pouco se coloca afirmativamente no intuito de definir a natureza e a função moral do prazer. Ademais, ao criticar a visão anti- 
hedonista, Aristóteles, por um lado, concorda com Eudoxo de que tudo o que parece ser prazeroso também parece ser bom (phainomenon agathon), mas, por outro lado, como nem tudo o que parece ser bom é bom e como nem todo prazer é bom, ele discorda de que o prazer ou mesmo um tipo de prazer poderia ser o bem supremo. A felicidade é prazerosa por ser necessariamente uma atividade desimpedida, pois que a sua perfeição não admitiria qualquer impedimento, interno ou externo; portanto, ser prazerosa constitui um de seus atributos necessários, mas não poderia ser suficiente para esgotar a sua definição.

Os ganhos conceituais da segunda definição de prazer

Certamente, é tese bem estabelecida na ética aristotélica que a ação virtuosa não deva ser desejada em vista do prazer, mas sim em vista de ela mesma ser virtuosa. Porém, como comumente desejamos o que nos aparece como prazeroso e o que nos aparece como prazeroso não nos fornece um critério moral aceitável, então, deve ser possível e necessário que o que nos apareça como prazeroso esteja condicionado ao que julgamos corretamente ser bom. Afinal, também é tese bem estabelecida que o critério moral deva ser o bom julgamento, i.e., aquele mesmo que o prudente faria.

Vejamos, agora, como a definição de prazer proposta no segundo Tratado corrobora com a tese de que o virtuoso age devido ao bem e não devido ao prazer, uma vez que o seu julgamento incidirá sobre a atividade e não sobre o prazer.

\section{A definição de prazer do segundo Tratado}

Pretendemos, agora, mostrar em que sentido a segunda definição do prazer e a tese da diferença específica entre os prazeres corroboram com a tese de que o prazer não poderia servir como o critério para a realização da boa atividade, bem como dissolve a armadilha conceitual armada pela primeira definição.

Depois de ter fornecido, em $E N X_{4}$, os atributos essenciais do prazer, a saber, que ele é um todo completo e indivisível e que a atualização de sua essência é imediatamente completa, Aristóteles fornece a definição de prazer no capítulo seguinte (1174b321175a22). Em verdade, a argumentação para se chegar à definição de prazer não é clara, tampouco é fácil de compreender. O filósofo a inicia fornecendo o primeiro atributo do prazer ao compará-lo com o ato de ver, a saber: ele é um todo completo, como o ato de 
ver, que não necessita de nada que venha a completar a atualização de sua forma ou essência (eîdos). Esse primeiro argumento prova que o prazer não é um movimento, pois todo movimento, por ser um meio para um fim, é incompleto (ateleios) até que seja finalizado, e o prazer, por ser um fim em si mesmo, é completo desde o início (1174a19b9). Com efeito, se o prazer não é um movimento, então resta apenas que ele seja, assim como o é a atividade de ver e pensar, uma atualização completa ou perfeita de sua natureza, i.e., uma atividade. Como ele diz:

A essência (eîdos) do prazer é completa em qualquer instante do tempo. Por isso, é evidente que o prazer não é o mesmo que o movimento, sendo um certo todo e algo completo (holôn ti kai teleiôn). Com efeito, não é possível se mover senão ao longo do tempo, mas é possível sentir prazer (hêdesthai), pois aquilo que existe em um instante é um todo completo (to gar entoi nun holon ti) (EN X, 4, 1174b6-9).

A argumentação é complexa e não caberia desenvolvê-la aqui em seus pormenores. ${ }^{33}$ Apenas cabe enfatizar novamente que dizer que sua atualização é completa desde que passou a existir implica dizer que o prazer é antes uma energeia, no sentido de atualização completa, do que um movimento, no sentido de atualização incompleta.

Fica evidente que o prazer é uma atualização completa (energeia teleia $)^{34}$, i.e., uma atividade e que, a partir de uma passagem do De Anima, ele deve ser entendido como uma atividade sensível de fruição. Como atesta o filósofo, temos a sensação de prazer quando, por meio da faculdade perceptiva, percebemos algo como sendo bom:

A sensação é, então, como a simples asserção ou simples pensamento (noeîn) e quando há algo prazeroso ou doloroso, a sensação, como que afirmando ou negando, busca ou evita. Com efeito, sentir prazer e dor é exercer uma atividade, por meio da faculdade perceptiva, em direção ao bem ou ao mal enquanto tais (kai esti to êdesthai kai lypeisthai to energein têi aisthêtikêi mesotêti pros to agathon ê kakon) (DA III 7: 431a8-13).

É preciso ter em mente que, na Ética Nicomaqueia, o filósofo estabeleceu uma analogia entre prazer e ver e não uma identificação. Ele mesmo insiste na distinção entre sensação e prazer no segundo Tratado. ${ }^{35}$ No De Anima, esta identificação tampouco ocorreria. Trata-se de compreender que o prazer não é idêntico, por exemplo, à sensação de ver, mas que pode ser entendido como uma atividade em direção ao bem ou ao que

\footnotetext{
${ }^{33}$ Ver mais em Aggio, 2017, pg. 82-89.

${ }^{34}$ Assim também concebem Gosling e Taylor (1982), cap. Kinesis and Energeia, parágrafo 16.2.6, pg. 312 .

${ }^{35}$ Cf. EN X 5: $1175 b 30-36$
} 
percebemos como sendo bom, portanto uma atividade que depende deste tipo particular de percepção, i.e., da percepção de algo bom ou de que algo apareça como sendo bom. Ou seja, se aquilo que vemos nós também o percebemos como sendo bom, então temos simultaneamente a sensação de ver algo e o prazer com o que vemos. Como se pode notar, há duas atividades simultâneas: a de ver algo e a de sentir prazer ao estar vendo algo. Em termos gerais, podemos dizer que há, simultaneamente, a atividade de apreender algo como sendo bom e a atividade de sentir prazer com isto que parece ser bom. Ademais, não há nenhuma contradição em afirmar que realizamos duas atividades simultaneamente, uma atividade principal e outra secundária, respectivamente, ver algo como um belo pôr do sol e, consequentemente, sentir prazer com isso. O prazer é uma atividade que se segue a outra, uma atividade-efeito coextensiva à atividade-causa. Ao comermos uma bela refeição, por exemplo, estamos atualizando simultaneamente diversas atividades: a atividade de ver as cores e ordenação do alimento, a atividade de sentir o bom odor da comida, a atividade de saborear o alimento e mesmo atividades cognitivas, como lembrar de algo, ou imaginar, ou pensar algo. Cada uma dessas atividades é acompanhada de seu prazer próprio. Logo, há várias atividades sendo realizadas e também prazeres sendo percebidos simultaneamente no ato de comer uma bela refeição.

O prazer, portanto, é uma atividade sensível, pois nós o percebemos quando sentimos prazer. Não haveria prazer se ele nos passasse desapercebido. Assim, o prazer é uma atividade sensível de fruição que ocorre necessariamente quando algo nos parece ser bom, i.e., quando se nos manifesta um bem aparente (phainomenon agathon). É importante enfatizar que o prazer, mesmo que ele seja uma atividade dependente da percepção, também pode ocorrer quando imaginamos, lembramos ou pensamos em algo bom; enfim, quando simplesmente algo nos aparece como sendo bom.

Todavia, dizer que ele é antes uma atividade (energeia) do que um processo ou um movimento, apenas nos garante que ele possa ser um bem. Ainda é preciso dizer em que sentido e sob quais critérios podemos efetivamente considerá-lo um bem, pois considerá-lo como um todo completo e indivisível certamente não nos fornece critério algum de valoração moral sobre a natureza do prazer. O critério, como veremos, dependerá da natureza da atividade à qual ele pertence. Passemos a definição propriamente dita. 
O prazer é definido como uma perfeição que sobrevém (epigignomenon ti telos) ${ }^{36}$ e retroage sobre a própria atividade (energeia) à qual pertence aperfeiçoando-a. Tal definição fora obtida da análise dos capítulos 4 e 5 como um todo, mas, sobretudo, das linhas 1174b33-35: “O prazer aperfeiçoa a atividade, não como uma disposição que reside no agente, mas como uma perfeição que sobrevém, como a flor da idade na vida”. Diante de tal definição, interessa-nos sobretudo entender em que sentido o prazer é próprio ou pertence (oikeia) a uma atividade. Deixemos de lado, para a presente análise, o seu atributo de ser capaz de aperfeiçoar (teleiô̂) a atividade. ${ }^{37}$ Brevemente, podemos dizer que oikeia significa "pertencer" ou "ser próprio a". No caso, o prazer que pertence a uma atividade é aquele que vem a ser em virtude da natureza da própria atividade que o agente está atualmente realizando. ${ }^{38}$

Com efeito, o prazer pertence à atividade de modo a não existir nem lógica nem ontologicamente em separado dela, pois não apenas a sua existência, mas também a sua definição dependem da existência e da definição da atividade. Ontologicamente, pois não há prazer sem atividade (1175a21); e, logicamente, pois não está nem no tempo, nem por natureza separado da atividade, ao contrário do desejo, que existe anteriormente à realização da atividade. Ou seja, o prazer é uma atividade que não subsiste por si mesma, mas é absolutamente dependente da atividade perceptiva ou noética a qual pertence. ${ }^{39}$

Por isso, não há definição do valor moral do prazer senão a partir do valor moral atribuído à atividade. E, como as atividades são distintas e variadas, também o serão os prazeres. Nas palavras do filósofo:

Diferindo as atividades quanto à bondade e à vileza, e sendo umas dignas de serem perseguidas, outras evitadas, e outras ainda neutras, o mesmo se dá também com os prazeres; pois, para cada

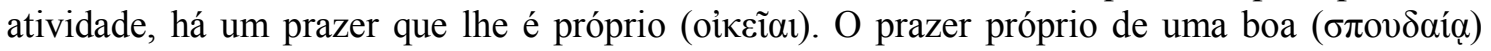

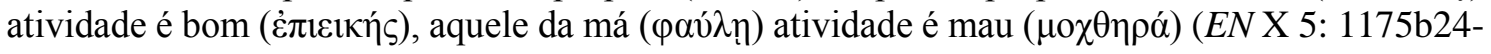
28).

A citação acima estabelece claramente a tese da diferença específica entre os prazeres, que, aos olhos de Alexandre de Afrodisia, nos conduzirá inevitavelmente à seguinte consequência:

\footnotetext{
${ }^{36}$ Cf. EN X, 4, 1174b33.

${ }^{37}$ Cf. EN X, 5, 1175a27-b1.

${ }^{38} \mathrm{Cf} . \mathrm{EN} \mathrm{X}, 5,1175 \mathrm{~b} 21-22$.

${ }^{39}$ De todo modo, o Estagirita nos diz que, mesmo sendo estreitamente unidos, seria absurdo confundir o prazer com a atividade à qual ele pertence (EN X, 5, 1175b30-34).
} 
não é dos prazeres produzidos que nós julgamos as atividades que os produzem, ao contrário, nós julgamos os prazeres pelas atividades. As atividades não merecerão ser escolhidas tendo em vista os prazeres, nem serão os prazeres os mesmos em espécie um em relação ao outro (Problema 13, $134,13-17)$.

Da tese da diferença específica, segue-se que a distinção entre as espécies de prazeres não poderia ser apenas acidental, ou seja, a diferença entre prazeres não é apenas porque acontece de existir certo prazer segundo certa atividade que difere de outro prazer segundo outra atividade, mas porque o prazer que acompanha a atividade lhe é próprio e se diferencia de outro prazer na mesma medida em que uma atividade se diferencia de outra, visto que sua natureza corresponde à da atividade. Isso explica o fato de que as atividades a serem evitadas pelo temperante (i.e., as atividades do intemperante) dificilmente lhe dariam prazer. ${ }^{40}$ Se não fosse assim, como diferenciaríamos os prazeres que acompanham as atividades vergonhosas dos que acompanham as louváveis? São as atividades vergonhosas e louváveis a causa da diferença entre os prazeres, pois, como diz Alexandre de Afrodisia, "as atividades não derivam o seu valor de escolha dos prazeres, mas os prazeres das atividades, já que é até mesmo por causa das atividades que os prazeres são de certo tipo" (Problema 23, 146, 3-5).

A consequência da definição do prazer como um próprio da atividade e como distinto dos outros conforme a atividade a qual pertence é que não há definição do valor moral do prazer senão a partir do valor moral atribuído à atividade. A partir deste argumento, não se poderia mais sustentar a máxima hedonista de que o prazer é o bem em absoluto; nem a máxima anti-hedonista de que ele é o mal em absoluto. Aristóteles parece se mostrar avesso a uma interpretação essencialista do valor moral do prazer. Afinal, com a tese da diferença qualitativa entre os prazeres e a sua definição como sendo absolutamente dependente da atividade à qual acompanha, faz-se evidente que a qualidade moral do prazer depende da qualidade moral da atividade à qual pertence e o valor da atividade, por sua vez, depende do bom julgamento do homem virtuoso.

Quanto à análise do segundo Tratado, podemos concluir que Aristóteles se preocupa menos em refutar o anti-hedonismo, como o fez no primeiro Tratado; por isso, a definição de prazer parece ser menos dependente da argumentação refutativa do que antes. Neste sentido, podemos inferir que a definição do prazer como uma atividade se constitui primordialmente em negação à definição platônica do prazer como um processo

${ }^{40}$ Cf. EN III 12: 1119a12-21. 
de geração ou movimento. Com esta refutação, abre-se a possibilidade de o prazer ser dito um bem. Já a definição do prazer como uma atividade sensível que aperfeiçoa a atividade à qual ele pertence, portanto, como sendo distinto da própria atividade que é prazerosa, permite que se possa estabelecer, com mais clareza, os critérios de valoração moral dos prazeres.

\section{Peroração}

Após termos feito a análise das duas definições de prazer fornecidas nos dois Tratados, parece ser natural apontarmos, em grandes linhas, as congruências e as divergências entre eles, de modo que fique mais clara a problemática tratada em cada um, bem como no que se refere propriamente à definição de prazer.

A primeira pergunta que poderíamos fazer é por que Aristóteles escreveu este segundo Tratado que, à primeira vista, não parece fazer qualquer referência explícita ao primeiro. As respostas dos intérpretes variam enormemente, mas, em geral, a maior parte $^{41}$ diz que este segundo Tratado é mais propriamente aristotélico e, portanto, mais refinado filosoficamente; enquanto o primeiro, por fazer parte dos livros comuns da $E E$ e $E N$, seria de um Aristóteles mais imaturo, ainda muito influenciado por Platão. De fato, a diferença entre os Tratados é considerável se tomarmos a definição do próprio objeto, o prazer, e verificarmos o quanto são distintas, mas há uma semelhança considerável: em ambos o prazer é dito ser uma atividade (energeia). Enquanto no primeiro, o prazer é simplesmente uma atividade, no segundo, ele é uma atividade que acompanha e aperfeiçoa outra atividade. Todavia, podemos supor que não há uma separação surda entre os Tratados e que, no segundo Tratado, Aristóteles revisaria e redefiniria com maior exatidão a noção de prazer, sem deixar de aproveitar os ganhos conceituais obtidos no primeiro Tratado.

Quanto a esta aparente inconsistência entre os Tratados, Owen ${ }^{42}$ nos fornece uma solução engenhosa, a saber, de que eles divergem por tratarem de questões distintas e, por divergirem em seus propósitos investigativos, ao serem comparados, não podem ser considerados inconsistentes. Segundo esse autor, a pergunta sobre o que é o prazer,

\footnotetext{
${ }^{41}$ Como, por exemplo, Festugière (1946); Gauthier (2002); Owen (1986, pp. 180-99); Zingano, M. (2007, pp. 297-330).

${ }^{42}$ Owen (1965).
} 
próprio do primeiro Tratado, é distinta da pergunta do segundo sobre o que é 'ter prazer', portanto os Tratados não são contraditórios se cotejarmos suas respostas, uma vez que elas serão distintas na medida em que respondem a perguntas distintas. Ou seja, elas são coerentemente distintas.

Segundo Gosling e Taylor ${ }^{43}$, os Tratados são díspares também por responderem a questões distintas, porém não às mesmas que estipula Owen: no primeiro, a pergunta é sobre se algum prazer é o bem e, no segundo, a pergunta é se o prazer é o bem. Diferentemente dos dois comentadores citados acima, Tomás de Aquino ${ }^{44}$ diz que a diferença entre o primeiro e o segundo é que o primeiro trata, sobretudo, dos prazeres corporais e o segundo trata do prazer enquanto um acréscimo à felicidade.

O ponto é que, a meu ver, não há duas perguntas diferentes. As perguntas são as mesmas: o que é o prazer e sob quais critérios ele seria um bem. Todavia, mesmo tratando das mesmas perguntas, as definições de prazer divergem essencialmente e isso é inegável. Se, no primeiro Tratado, o filósofo identifica o prazer com a atividade com vistas a refutar a concepção platônica de que o prazer é um movimento e não o fim do movimento, assim ele procede para garantir a possibilidade de que o prazer possa ser considerado um bem. O problema é que esta definição nos garante a possibilidade de o prazer ser um bem, mas não nos fornece os exatos critérios para a valoração moral do prazer. Isso porque o único critério fornecido brevemente e sem desdobramentos posteriores é de que a qualidade moral do prazer depende da retitude de seu objeto e do modo moderado de desejá-lo, portanto, da retitude do caráter do agente. Digo brevemente, pois o filósofo não nos diz como se justificaria esta dependência e se fundamentaria a própria necessidade destes critérios.

Já no segundo Tratado, visto que a atividade é distinta do prazer, ela pode ser o objeto de julgamento do agente moral e não o prazer. Ou seja, a ação moral sobre a qual o agente é inteiramente responsável passa a ser determinante na qualificação do valor moral do prazer. Na verdade, com este segundo Tratado, fica evidente a relação entre o bom objeto e o bom desejo para se obter o bom prazer. Se ter prazer nada mais é do que ter prazer com certa atividade, o objeto do prazer é a atividade. Assim, desejar ter prazer é desejar realizar certa atividade considerada prazerosa. Logo, o bom desejo incide sobre o bom objeto, i.e., a boa atividade e o bom prazer decorre da realização da boa atividade.

\footnotetext{
${ }^{43}$ Gosling e Taylor (1982).

44 Tomás de Aquino (1993).
} 
Isso significa que o critério para o prazer ser bom é a boa atividade. E o critério para a boa atividade é o bom caráter, i.e., razão e desejo retos. Evidentemente, se a ação for correta, ela incidirá sobre o objeto prazeroso correto e o agente saberá desejá-lo na justa medida.

Ademais, a definição do primeiro Tratado suscita a possibilidade de o prazer ser identificado ao bem supremo, já que ele é concebido como uma atividade desimpedida e a felicidade, por ser perfeita, também é necessariamente uma atividade desimpedida. Vimos, porém, que conceber tal possibilidade hipotética não é senão, a título argumentativo, reforçar a refutação, e não, de fato, assumir a tese hedonista de que o prazer realmente seja o bem supremo.

Em suma, as definições divergem, pois os propósitos divergem. Aristóteles, no primeiro Tratado, parece querer provar que o prazer possa ser certo bem, e assim o fez identificando prazer e atividade. Já no segundo Tratado, ele pretende distinguir prazer e atividade prazerosa de modo a evitar a possível identidade entre prazer e felicidade, o que lhe obriga a fornecer com maior precisão os critérios de avaliação da natureza moral do prazer. Sendo assim, como o prazer é uma perfeição que sobrevém à atividade que ele pertence, a sua natureza e existência dependem inteiramente da natureza e da existência da atividade. Portanto, com esta nova definição, podemos compreender mais claramente que o prazer é distinto da atividade prazerosa e não poderia ser identificado com a melhor e mais prazerosa atividade: a felicidade. Do mesmo modo, a qualidade moral do prazer será concebida conforme a qualidade moral da atividade à qual ele pertence e a sua função moral será a de poder aperfeiçoá-la. Ao que tudo indica, podemos afirmar que a definição do segundo Tratado é nitidamente mais sofisticada e mais relevante para a armadura conceitual da ética.

Além dos propósitos e das definições serem distintos, evidentemente, também serão os caminhos argumentativos. No primeiro Tratado, Aristóteles faz uso de argumentos de Eudoxo, se aproximando assim do extremo hedonismo com vistas a refutar o anti-hedonismo de Platão e de Espeusipo, e, com essa estratégia refutativa, a única tese propositiva que ele formula é a de que o prazer pode ser um bem. Já no segundo Tratado, Aristóteles passa a criar as bases para sustentar o seu hedonismo moderado, distanciandose, portanto, do radicalismo hedonista de Eudoxo ao mostrar que ele é, em parte, falso e, em parte, verdadeiro. A pergunta que se coloca é se o prazer pode ser o bem ou o mal em absoluto e a resposta, a partir da definição de prazer como um próprio da atividade, é negativa, pois ele deve depender da atividade para ganhar algum atributo moral. 
É plausível, a meu ver, supor que, por causa da necessidade de se provar que o prazer é um bem, o filósofo teve que identificá-lo tout court à atividade, o que gerou a possível identificação com a felicidade. Como, evidentemente, Aristóteles não assumiria tal identificação, própria de um hedonismo exagerado, surge a necessidade de provar que o prazer não é a felicidade, mas apenas condição necessária para tanto. Sendo assim, podemos supor que a investigação do segundo Tratado é motivada por uma dificuldade posta pelo primeiro, o que parece indicar o vínculo lógico entre ambos os Tratados.

Ademais, o problema do primeiro Tratado de identificar prazer e atividade não se traduz apenas em ter que decidir se a felicidade consistiria em alguns prazeres ou em uma classe de prazeres, como argumenta Owen. ${ }^{45}$ Os problemas que se sucederiam, a meu ver, seriam dois. O primeiro seria suscitar uma possível identificação inapropriada entre felicidade e prazer. O segundo seria cometer uma contradição lógica, que Aristóteles mesmo salienta no segundo Tratado, a saber: a identificação entre duas atividades de natureza distintas que, portanto, não podem ser coextensivas: a atividade perceptiva ou intelectiva e a atividade de sentir prazer. Ou seja, não se pode, sob pena de cair em contradição, identificar perceber ou pensar e ter prazer. Por isso, o coração da argumentação do segundo Tratado se encontra na tese de que o prazer e a atividade são inseparáveis, todavia distintos. O prazer é uma atividade sensível que depende de outra atividade para existir, pois sentimos prazer (atividade 2) ao realizarmos certa atividade (atividade 1), como ver o pôr do sol, desvendar um problema de matemática, ser generoso com seu amigo, produzir uma bela música etc. A atividade 2 depende lógica e ontologicamente da atividade 1 .

Deve-se, portanto, abandonar a definição de que o prazer é simplesmente uma atividade desimpedida conforme a nossa natureza. Ora, as atividades perceptiva e intelectiva são desimpedidas e conforme a nossa natureza quando a faculdade e objeto se encontram em boas condições, mas não são, elas mesmas, o próprio prazer que delas decorre. Mesmo que o prazer possa ser dito um tipo de atividade (energeia), enquanto atualização completa, ainda assim, ele não pode ser identificado ao perceber e ao pensar, que são atividades (energeiai) de outro tipo, de outra natureza, portanto, com definiçãao distinta. Ter prazer não pode ser confundido com a própria apreensão da faculdade perceptiva de certo objeto sensível ou com a própria apreensão da faculdade intelectiva de certo objeto noético. Logo, o problema não estaria em ter de determinar qual prazer

${ }^{45}$ Owen (1965). 
seria o bem supremo, mas de assumir a contradição oriunda da identificação tout court entre prazer e atividade. Nas palavras do filósofo:

o desejo é, tanto no tempo como por natureza, distinto da atividade; já o prazer é extremamente vinculado à atividade, de fato tão inseparável da atividade, que surge a dúvida se o prazer e a atividade ${ }^{46}$ não são a mesma coisa. Contudo, não devemos considerar que o prazer seja realmente uma sensação ou um pensamento, pois isso é absurdo; embora sejam inseparáveis, a alguns parece o mesmo (EN X 5: 1175b30-36).

Fica claro, pois, que, no segundo Tratado, o prazer é distinto da atividade à qual ele acompanha, ainda que seja ontologicamente inseparável, ou seja, a sensação ou o pensamento são distintos do prazer, mas podem vir acompanhados dele.

Por fim, a distinção entre os dois Tratados incide na definição de prazer, no propósito desta definição, bem como na trajetória argumentativa para obtê-la. Porém, apesar dessa diferença, há um vínculo lógico entre os Tratados, pois o segundo pretende resolver a possível e problemática identidade entre prazer e bem supremo legada pelo primeiro Tratado. Com efeito, alguns ganhos conceituais do primeiro são preservados e retomados no segundo Tratado, como (i) a refutação da concepção platônica de que o prazer não seria um bem por ser um processo sensível; (ii) a refutação da concepção de Espeusipo de que o prazer é em absoluto o mal; (iii) a distinção entre prazer natural e antinatural ou excessivo; (iv) a concepção de prazer por acidente; (v) a tese de que os prazeres próprios do pensar não o impedem, mas apenas os prazeres alheios; ao contrário, eles nos fazem pensar e aprender mais. Dizer, em VII 12 (1153a22), que os prazeres próprios do pensamento nos fazem pensar e aprender mais já é um prenúncio da definição de prazer do segundo Tratado como aquilo que é capaz de aperfeiçoar a atividade. Com efeito, a distinção entre prazer próprio e prazer alheio à atividade também será retomada no segundo Tratado, em X 5 (1175a30-b33). Por fim, o principal atributo da definição de prazer será retomado: o de que ele é uma atividade, um todo completo, portanto, de que ele não é um movimento, um todo incompleto. A diferença é que o prazer será uma atividade absolutamente dependente de outra no segundo Tratado, seja esta cognitiva, produtiva, artística ou moral. O tipo de prazer dependerá do tipo de atividade que o gera e o tipo de atividade dependerá daquele que a realiza. Podemos concluir que não há apenas compartilhamento de certos conceitos, como o segundo Tratado resolve o

\footnotetext{
${ }^{46}$ É preciso enfatizar que, neste momento, Aristóteles está se referindo à atividade de perceber ou de pensar, portanto, não se trataria de negar que o prazer seja uma atividade em termos absolutos, mas que ele não seja a atividade que ele acompanha.
} 
problema da identificação entre prazer e felicidade legado pelo primeiro Tratado, o que desfavorece a interpretação de que não haveria continuidade alguma entre os dois Tratados.

Juliana Aggio

Universidade Federal da Bahia

Referências Bibliográficas

Aristóteles. Opera ex recensione I. Bekker. Berlin: Academia Regia Borussica, 1831 [1960].

Aristóteles. Aristotle: metaphysics Books 4, 5 e 6. Tradução de Christopher Kirwan. Oxford: Oxford University Press, 2003.

Aristóteles. Aristotle: Nichomachean Ethics. Tradução de Christopher Rowe. Oxford: Oxford University Press, 2002.

Aristóteles. Ética a Nicómaco. Tradução de María Araujo , Julián Marías. Madrid: Centro de Estudios Políticos y Constitucionales, 2002.

Aristóteles. Retórica. Tradução de de Paulo Farmhouse e Alberto e Abel do Nascimento Pena. São Paulo Martins Fontes, 2012.

Aristóteles. Rhétorique. Tradução de Pierre Chiron. Paris: Flammarion, 2007.

Aristóteles. Nichomachean Ethics. Tradução de Terence Irwin. Indianapolis: Hackett Publishing, 1999.

Aristóteles. Works of Aristotle. In: ROSS, W. D. (Org.). The Great Books. Oxford: University Press, 1980.

Aristóteles. The nichomachean ethics.Tradução de Rackham. Havard: Loeb Classical Library, 1962.

Platão. A República. São Paulo: Martins Fontes, 2006.

Platão. The Dialogues of Plato. In: JOWETT, B. (Org.). The Great Books. Oxford: Encyclopedia Britannica, 1952.

Platão. Republic. Tradução de Paul Shorey. Cambridge: Harvard University Press, 1930.

Ackrill, J. L. Energeia and Kinêsis. In: Essays on Plato and Aristotle. Oxford: Clarendon Press, 1997.

Aggio, J. Prazer e desejo em Aristóteles. Salvador: Edufba, 2017. 
Alexander of Aphrodisias. Ethical Problems. Tradução de Sharples. New York: Cornell University Press, 1990.

Annas, J. Aristotle on Pleasure and Goodness. In Rorty, A. O. Essays on Aristotle's Ethics. California: University of California Press, 1980.

Aspásio: On Aristotle Nichomachean Ethics, 1-4, 7-8. Londres: Duckworth, 2006.

[150, 18-24].

Aubry, G. Nicomachean Ethics VII 14, (1154a22-b34): The Pain of the Living and Divine Pleasure. In: Natali, C. (Ed.). Aristotle: Nicomachean Ethics, Book VII - Symposium Aristotelicum. Oxford: Oxford University Press, 2005. p. 237-263.

Barnes, J. The Cambridge Companion to Aristotle. Cambridge, 1995.

Festugière, A. J. Aristote: Le plaisir. Paris: J. Vrin, 1946.

Frede, D. Nicomachean Ethics VII 11-12: Pleasure. In: Natali, C. (Ed.). Aristotle: Nicomachean Ethics, Book VII - Symposium Aristotelicum. Oxford: Oxford University Press, 2005. p. 183-207.

Frede, D. Prazer e dor na ética aristotélica. In: KRAUT, R. Aristóteles: A Ética a Nicômaco. Rio Grande do Sul: Artmed, 2009. p. 236-253.

Gauthier, R. A. L'Éthique à Nicomaque. Paris: Peeters, 2002. tomos I e II.

Gosling, J. C. B.; Taylor, C.C.W. The Greeks on Pleasure. Oxford: Clarendon Press, 1982.

Owen, G. E. L. Aristotelian Pleasures. In: Barnes, J.; Schofield, M.; Sorabji, R. Articles on Aristotle: Ethics and Politics. London: Duckworth, 1977.

Owen, G. E. L. Prazeres Aristotélicos. In: Zingano, M. (Org.). Sobre a Ética Nicomaqueia de Aristóteles. São Paulo: Odysseus, 2010.

Rapp, C. Nicomachean Ethics VII 13-14 (1154a21): Pleasure and eudaimonia. In: Natali, C. (Ed.). Aristotle: Nicomachean Ethics, Book VII - Symposium Aristotelicum. Oxford: Oxford University Press, 2005, p. 209-235.

Riel, G.V. Pleasure and Good Life: Plato, Aristotle and the Neoplatonists. Leiden: Brill, 2000.

Rorty, A. O. Akrasia and Pleasure: Nicomachean Ethics Book 7. In: Rorty, A. O. Essays on Aristotle's Ethics. California: University of California Press, 1980.

Rorty, A. O. The Place of Pleasure in Aristotle's Ethics. Mind, Oxford, v. 83, n. 332, p. 481-497, 1974.

Tomás de Aquino. Commentary on Aristotle's Nicomachean Ethics. Notre Dame: Dumb Ox Books, 1993.

Zingano, M. Estudos de Ética Antiga. Porto Alegre: Discurso Editorial, 2007. Coleção Philosofia).

Zingano, M. (Org.). Sobre a Ética Nicomaqueia de Aristóteles. São Paulo: Odysseus, 2010 . 